\title{
Animals models of $\mathrm{MCH}$ function and what they can tell us about its role in energy balance
}

\author{
Pavlos Pissios \\ Division of Endocrinology, Diabetes and Metabolism, Beth Israel Deaconess Medical Center, \\ Boston, MA 02446
}

\begin{abstract}
Melanin-concentrating hormone ( $\mathrm{MCH})$ has attracted considerable attention because of its effects on food intake and body weight and the $\mathrm{MCH}$ receptor (MCHR1) remains one of the viable targets for obesity therapy. This review summarizes the literature examining the effects of $\mathrm{MCH}$ on body weight, food intake and energy expenditure in rodent models, and the central sites where $\mathrm{MCH}$ acts in regulating energy homeostasis. Emphasis is given on the discrepancies between the genetic and pharmacologic models of MCHR1 inactivation. We propose some solutions to resolve these discrepancies and discuss some future directions in $\mathrm{MCH}$ research.
\end{abstract}

\section{Introduction}

Melanin-concentrating hormone (MCH) is a peptide originally isolated from fish as a regulator of skin color [22]. The mammalian melanin-concentrating hormone (MCH) is a 19 amino acid cyclic peptide selectively expressed in lateral hypothalamic neurons. $\mathrm{MCH}$ neurons project widely throughout the central nervous system from the olfactory bulb to the spinal cord [6]. $\mathrm{MCH}$ acts through two G-protein coupled receptors MCHR1 and - 2 in humans, dogs and ferrets but rodents express only MCHR1 [58]. The position of the $\mathrm{MCH}$ neurons in the lateral hypothalamic area, the widespread projections of the $\mathrm{MCH}$ neurons and the broad expression of the MCHR receptors suggested that this peptide might regulate various functions such as arousal, sensorimotor integration and motivated behaviors [37]. Several recent reviews summarize the various functions of $\mathrm{MCH}[40][38,45]$. In this manuscript, we focus on the regulation of appetite and energy expenditure by $\mathrm{MCH}$.

\section{Genetic manipulation of $\mathrm{MCH}$ expression}

The first mouse model of MCH deletion published by the Maratos-Flier lab [51] demonstrated the role of $\mathrm{MCH}$ in energy balance with decreased body weight and resistance to diet induced obesity (DIO). Lower food intake and increased energy expenditure were proposed to account for the body weight phenotype. The mice in this study were on a mixed background (129SvJXC57BL6) and crossing of this mouse model to different backgrounds produced slightly different phenotypes, albeit both DIO resistant. MCH-KO mice on C57BL/6 background increased their activity and energy expenditure but MCH-KO on the 129/SvEv background were actually hyperphagic with increased energy expenditure accounting for their leanness [24]. The reduced adiposity of MCH-KO mice persists at least for 19 months with significantly improved glucose homeostasis [21].

\footnotetext{
Publisher's Disclaimer: This is a PDF file of an unedited manuscript that has been accepted for publication. As a service to our customers we are providing this early version of the manuscript. The manuscript will undergo copyediting, typesetting, and review of the resulting proof before it is published in its final citable form. Please note that during the production process errors may be discovered which could affect the content, and all legal disclaimers that apply to the journal pertain.
} 
The Maratos-Flier group has also reported an overexpression model of $\mathrm{MCH}$ [28].

Approximately a 2 -fold increase in $\mathrm{MCH}$ expression was adequate to cause moderate obesity and increase food intake in mice. High-fat diet feeding was required to reveal the obese phenotype on the FVB background but the obesity prone C57BL/6 background revealed the obese phenotype even on the low-fat chow diet. It was noted that the hyperinsulinemia in this background was disproportionate to the degree of obesity, suggesting an effect of $\mathrm{MCH}$ on the islet independent of obesity [28]. Later studies showed that MCH has direct effects on the beta cells, suggesting that $\mathrm{MCH}$ might have peripheral actions in addition to central effects in regulating glucose metabolism [56] [42].

Recently, a mouse model expressing the ataxin-3 toxin in $\mathrm{MCH}$ neurons has been reported [2]. Approximately 60-70\% of $\mathrm{MCH}$-expressing neurons progressively degenerate in the first few weeks in life leading to late onset leanness, hypophagia and increased energy expenditure. Crossing of the MCH/ataxin-3 mouse with the ob/ob mouse resulted in decreased body weight and significantly reduced blood glucose. The $\mathrm{MCH} /$ ataxin- 3 mouse essentially recapitulates the $\mathrm{MCH}-\mathrm{KO}$ mouse phenotype. This finding suggests that $\mathrm{MCH}$ is the main peptide in these neurons regulating energy homeostasis, although the contribution of other peptides (NGE, NEI, CART) and classical neurotransmitters (GABA) encoded by these neurons cannot be excluded. Perhaps significantly, this mouse model shows hypophagia, which is consistent with the action of $\mathrm{MCH}$ as an orexigenic peptide. This finding contrasts to the other models of $\mathrm{MCH}$ or MCHR1 deletion (see below), which show either no changes in food intake or hyperphagia. Although the $\mathrm{MCH}$ neurons express other neurotransmitters in addition to $\mathrm{MCH}$, it is tempting to speculate that the relatively late onset deletion of $\mathrm{MCH}$ neurons limits the compensatory response of the central nervous system to $\mathrm{MCH}$ absence, revealing the orexigenic function of $\mathrm{MCH}$ in this model.

\section{Genetic inactivation of MCHR1 expression}

Mice have one G-protein coupled receptor with high affinity for MCH (MCHR1) expressed widely in the central nervous system $[4,11,26,46,52]$. The MCHR1 was genetically ablated independently by several groups $[3,12,32]$. All studies consistently show increased leanness (decreased adiposity) in MCHR1-KO mice on chow diet and more prominently on a high fat diet. The major mechanism behind the leanness appears to be increased energy expenditure, with likely contribution from increased locomotor activity and from increased resting energy expenditure. The increase in the resting energy expenditure appears to be at least in part through the increase in sympathetic activity in MCHR1-KO mice and likely through the brainstem projections of MCH neurons [3]. Paradoxically, MCHR1-KO mice show significant hyperphagia and also hyperactivity. Since treatment with MCHR1 antagonists do not increase but rather decrease food intake in rodents (see below), the observed hyperphagia in MCHR1$\mathrm{KO}$ mice has been interpreted as a compensatory response of the MCHR1-KO mice to the decreased adiposity or as a developmental aberration of unclear physiological significance caused by the absence MCHR1 signaling during development. The hyperactivity phenotype has also been followed up with several studies showing increased sensitivity of the mesolimbic dopamine system in the MCHR1-KO and MCH-KO mice [41,53,54,60,62]. In contrast, treatment of rodents with $\mathrm{MCH}$ or MCHR1 antagonists does not change their locomotor activity $[17,50]$. This discrepancy makes the role of $\mathrm{MCH}$ in regulating locomotor activity unclear, but it points out to an important region of $\mathrm{MCH}$ actions outside the hypothalamus (nucleus accumbens) involved in reward to food.

\section{Effect of MCH deletion in leptin-deficient background}

Both MCH-KO and MCHR1-KO mice have been crossed with the leptin-deficient ob/ob mice. Crossing the $\mathrm{MCH}-\mathrm{KO}$ mice to the leptin-deficient background caused a significant reduction 
in body weight of the double null mice with improved glucose homeostasis. The weight loss occurred despite similar food intake of the double knockout mouse to the ob/ob mouse suggesting that increased energy expenditure (app. 25\%) and 3-fold increased locomotor activity (3-fold) accounted for the leanness in this model [49]. When exposed to cold, the double knockout mice maintained their temperature better than the ob/ob mice. Evidence for increased thermogenesis in this model was also supported by the increased UCP-1 expression in the brown adipose tissue [49].

Some differences between the two models emerged when MCHR1-KO were crossed to the leptin-deficient background. The mice did not have decreased body weight compared to ob/ob mice, but adiposity decreased and glucose homeostasis improved in the double knockout mice [7]. Improved core body temperature was also noted but UCP-1 levels were not changed. The absence of weight loss contrasts with the phenotype of the $\mathrm{MCH}$ ob/ob double knockout mice, which are significantly leaner. One hypothetical explanation for the discrepancy between the peptide and the receptor knockouts could be the activity of other neuropeptides encoded by the proMCH gene, NEI or NGE, which are deleted in the MCH-KO but present in the MCHR1KO mice. Although NEI has been reported to have locomotor and behavioral effects in rodents [48] its role if any in body weight regulation will need to be resolved by additional experiments.

\section{Central effects of $\mathrm{MCH}$ on energy balance}

The first report of the orexigenic effect of MCH in rats was published by in 1996 by the MaratosFlier lab and stimulated the interest in the action of this peptide. The effect is transient, it lasts for 2-4 hours and results in 2-3 fold increase in cumulative food intake [43,44]. In comparison to NPY, the prototypical orexigenic peptide, the effect of $\mathrm{MCH}$ on food intake is similar in duration with that of NPY but more modest in magnitude (MCH 2-3 fold vs NPY 8-fold) $[27,55]$. The effect of $\mathrm{MCH}$ administration is not limited to food as it also increases sucrose and alcohol intake [15,47]. Water intake is also increased by $\mathrm{MCH}$ independently of food intake $[13,36]$. Several studies examined the effect of chronic MCH infusion on food intake and body weight in mice and rats $[14,17,50]$. Chronic infusion of peptide $\mathrm{MCH}$ agonist in rats increased cumulative food intake and body weight gain on a moderately high fat diet by $38 \%$ compared to a control group [50]. Increased caloric efficiency with $\mathrm{MCH}$ infusion was also noted, suggesting that $\mathrm{MCH}$ infusion promotes not only the accumulation of calories though increasing food intake but also promotes their storage in the adipose tissue [50]. Similarly, chronic infusion in mice increased food intake and body weight gain. The effect of $\mathrm{MCH}$ was apparent even on chow diet but was exaggerated by a moderately high fat diet [17]. Increased food intake appears to account for most of the observed increase in body weight because pairfeeding the MCH-infused groups normalized the body and fat pad weight [20]. However, increased lipogenesis in the liver and white adipose tissue were not normalized by pair-feeding suggesting that $\mathrm{MCH}$ might affect peripheral lipid metabolism independent of its effects on food intake and body weight [20]. A recent study also supports this observation [18]. The precise sites of $\mathrm{MCH}$ actions in affecting peripheral substrate utilization are only now being investigated and should provide important insight into the metabolic effects of $\mathrm{MCH}$.

\section{Effects of MCHR1 antagonists on energy balance}

Several peptidic antagonists for the MCHR1 have been synthesized in an attempt to decrease body weight by pharmacological manipulation of the MCHR1 signaling [5]. Acute injections of MCHR1 antagonists do not produce a significant decrease in food intake but, as expected, block the orexigenic effect of $\mathrm{MCH}[33,36,50]$. On the other hand, central nervous system infusions of peptidic MCHR1 antagonists over 14 days reduced food intake by $16 \%$ and body weight gain by $35 \%$ in rats [50]. Similar results are also seen with mice. Chronic infusion of MCHR1 antagonists over a 4-week period also completely prevented the body weight increase 
in mice fed a high fat diet. It decreased the adiposity, fat pad weight and improved the hepatosteatosis of MCHR1 antagonist infused group. Blood glucose, insulin and cholesterol were also improved [33]. Importantly, the same antagonist is ineffective in reducing food intake and body weight in MCHR1-KO mice, demonstrating that the selective manipulation of the $\mathrm{MCH}$ system is responsible for the observed changes [33]. No changes in locomotor activity were observed in the studies with either the peptidic agonists or antagonists of MCHR1, suggesting that the locomotor phenotype is unique to the genetic models of MCH or MCHR1 inactivation.

Pharmaceutical companies have devoted a considerable effort in the development of small molecule antagonists for the MCHR1. Several structurally distinct small molecule antagonists have been synthesized and tested in cell-based assays for their selectivity and affinity and for potency in rodents. Comprehensive review of these experiments is outside the scope of this review. For examples of the hurdles the pharmaceuticals companies face in achieving the desired selectivity and efficacy of MCHR1 antagonists interested readers should consult some recent reviews [30,34]. In agreement with the peptide infusions described above, the small molecule antagonists of MCHR1 consistently reduce body weight and protect against DIO. The first reports in 2002 demonstrated that small molecules MCHR1 antagonists are a viable approach for obesity therapy [9,57]. The first orally active MCHR1 antagonist was published by Takeda and was effective in reducing food intake stimulated by icv injection of $\mathrm{MCH}$ in rats [57]. Another compound, SNAP-7491 (Synaptic) was also effective in blocking MCHinduced increase in food intake. Daily administration of SNAP-7491 reduced body weight gain in lean rats. The compound was also effective in reducing the weight of DIO rats by $26 \%$ after 4 weeks of treatment [9]. Several other small molecule MCHR1 antagonists have been synthesized by pharmaceuticals companies and many studies show their effectiveness in reducing food intake and body weight in rodents. It is unclear what the relative contribution of energy expenditure and reduced food intake is in producing weight loss with these compounds, as most of these studies do not report data on energy expenditure, for examples see $[25,31,59]$.

Although most of these compounds are screened for specificity, some affinity towards others receptors (e.g. serotonin receptors) has been observed with some classes of MCHR1 antagonists [30]. Therefore the contribution of others receptors in reducing food intake cannot be excluded and ideally these compounds should be evaluated in MCHR1-KO mice. A recent publication by Gehlert et al, is a good example of a carefully done study, which used MCHR1$\mathrm{KO}$ mice as a negative control for the small molecule MCHR1 antagonist GW803430 to show that the reduction in body weight and food intake are specific through antagonism of the MCHR1. The authors also describe anxiolytic and antidepressant effects, which have been noticed with other MCHR1 antagonists as well. Anxiolytic and antidepressants effects of MCHR1 antagonists would certainly be desirable in treating obese populations. The behavioral actions of $\mathrm{MCH}$ not related to energy balance are described elsewhere in this issue.

\section{Central sites of MCHR1 signaling regulating energy homeostasis}

The widespread expression of the MCHR1 in the CNS complicates considerably the investigation of the sites $\mathrm{MCH}$ acts in regulating energy homeostasis. The sites of $\mathrm{MCH}$ action regulating energy metabolism have been addressed by a few studies. The hypothalamus was the first site of $\mathrm{MCH}$ actions to be investigated. All the information has been derived from sitespecific injections of MCH or MCHR1 antagonists, as conditional deletions of MCHR1 from specific hypothalamic nuclei have not been reported to date to provide genetic evidence of sitespecific MCH actions. Pharmacological doses of MCH significantly stimulate food intake in rats when injected into the dorsomedial, the arcuate and the paraventricular nucleus of the hypothalamus [1]. Although these results suggests the potential sites of $\mathrm{MCH}$ action in the 
hypothalamus, further experiments will be required to test if they are the physiologically relevant sites of $\mathrm{MCH}$ action.

The phenotype of the MCH-KO and MCHR1-KO mice, suggested that $\mathrm{MCH}$ might also act outside the hypothalamus and this notion is supported by the strong expression of MCHR1 outside the hypothalamus [19]. Both knockout models exhibit hyperactivity and sensitivity to psychostimulants, which has been interpreted as $\mathrm{MCH}$ acting in the mesolimbic dopamine system and more specifically in the medial shell of the nucleus accumbens, which strongly expresses MCHR1 receptors. Although, the effects on locomotor activity are not reproduced with $\mathrm{MCH}$ or MCHR1 antagonists, injections of $\mathrm{MCH}$ into this nucleus increase food intake but not substrate oxidation [16,18]. The increase in food intake after $\mathrm{MCH}$ administration is consistent with the inhibitory nature of MCHR1 signaling as injections of muscimol (GABA receptor agonist) into the shell of the nucleus accumbens also potently stimulate food intake.

On the other hand, caudal projections of MCH neurons to the dorsal vagal complex-NTS of the brainstem might be expected regulate autonomic responses but not feeding. This notion has been supported by injections of MCH into the $4^{\text {th }}$ ventricle, which decrease core body temperature but do not affect food intake [61]. Central infusions of $\mathrm{MCH}$ or injections into the medial NTS decrease blood pressure and heart rate in rats $[10,35]$. Genetic mouse models also support the autonomic effects of MCH. MCHR1-KO mice have increased sympathetic activity and increased heart rate [3]. Deletion of $\mathrm{MCH}$ from leptin-deficient mice increases their cold tolerance and expression of UCP-1 in brown adipose tissue and MCH knockdown using antisense oligonucleotides has similar effects in the rat [39]. Additional effects of $\mathrm{MCH}$ on energy balance might be mediated through its effects on neuroendocrine systems as $\mathrm{MCH}$ suppresses the hypothalamic-pituitary-thyroid axis [23].

\section{Discrepancies between the genetic and the pharmacological models of $\mathrm{MCH}$ function}

All rodent models consistently show that acute or chronic $\mathrm{MCH}$ infusion increases appetite and body weight. On the other hand, inactivation of the MCHR1 results in body weight loss and/or decreased adiposity (Table 1 summarizes the phenotypes discussed in this manuscript). However, some discrepancy is apparent between the models regarding the mechanisms by which $\mathrm{MCH}$ regulates body weight. The pharmacological models point to the regulation of food intake as the major factor with some contributions from changes in energy expenditure. On the other hand, the genetic models of MCH or MCHR1 inactivation suggest that the increased energy expenditure is the major mechanism underlying their leanness. Food intake in these models is either not changed or in some actually increased and in contrast to the orexigenic actions of $\mathrm{MCH}$. The same models also show increased locomotor activity not seen with pharmacological infusions of MCH or MCHR1 antagonists. Some of the differences could be due to the use of different models, mice versus rats, different genetic background, diets and other experimental details. However it is unlikely that methodological differences can account for all the discrepancies. A more plausible and worrying explanation is that the knockout models suffer from developmental adaptations due to absence of $\mathrm{MCH}$ signaling and emerge with phenotypes not representative of $\mathrm{MCH}$ functions in the adults. For example, the hyperphagia of the MCHR1-KO mice has been interpreted as a compensatory adaptation to the decreased adiposity but chronic (weeks) pharmacological blockade of MCHR1 receptor in mice decreases both food intake and body weight. Although it is in principle possible that a longer blockade of the MCHR1 in adult animals could eventually reach a point where compensatory pathways would negate the effects of MCHR1 antagonists on food intake, it seems unlikely that the animals would actually become hyperphagic like the MCHR1-KO mice and such an outcome remains to be demonstrated. The problem of developmental compensations is of course a much larger issue affecting neuroscience research in general. 
With regard to the hypothalamic regulation of feeding, perhaps the most compelling evidence on the plasticity of the hypothalamus has been provided by the elegant study from the Palmiter group. In this study, the diptheria toxin was used to selectively ablate the NPY/AGRP neurons of the arcuate nucleus of the hypothalamus. When the ablation of the NPY/AGRP neurons occurred during the early postnatal life, feeding was minimally disrupted. In contrast, ablation later in life caused death from starvation [29].

Although the knockout models are invaluable in studying the function of specific genes, the capacity of the central nervous system for adaptation can also limit their usefulness in studying complex behaviors. One way of potentially eliminating these artifacts would be the use of conditional and inducible knockouts [8], which would provide site specificity and temporal control over $\mathrm{MCH}$ actions and would be expected to decrease any compensatory artifacts.

\section{Concluding Remarks}

Significant progress has been made towards our understanding of $\mathrm{MCH}$ actions in regulating appetite and energy balance. However several challenges remain. For example, the pathways through which MCH affects peripheral energy and substrate utilization need to be more thoroughly investigated. The interaction of $\mathrm{MCH}$ neurons with other circuits such as the mesolimbic dopamine system and the sleep circuitry are other exciting areas of research. The function of the second $\mathrm{MCH}$ receptor MCHR2 in energy balance is unknown and it will require the use of other animal models such as ferrets and dogs. Perhaps more importantly, the $\mathrm{MCH}$ actions need to be placed in a physiological context. Very little is known about the activity of $\mathrm{MCH}$ neurons under various conditions such as feeding and fasting, high fat-low fat diets and obesity. Addressing these questions might require the development of new tools but it will keep the $\mathrm{MCH}$ research active and fruitful for years to come.

\section{Acknowledgments}

This work was supported by National Institutes of Health DK56113 and DK56116.

\section{References}

1. Abbott CR, Kennedy AR, Wren AM, Rossi M, Murphy KG, Seal LJ, et al. Identification of hypothalamic nuclei involved in the orexigenic effect of melanin-concentrating hormone. Endocrinology 2003;144:3943-9. [PubMed: 12933668]

2. Alon T, Friedman JM. Late-onset leanness in mice with targeted ablation of melanin concentrating hormone neurons. J Neurosci 2006;26:389-97. [PubMed: 16407534]

3. Astrand A, Bohlooly YM, Larsdotter S, Mahlapuu M, Andersen H, Tornell J, et al. Mice lacking melanin-concentrating hormone receptor 1 demonstrate increased heart rate associated with altered autonomic activity. Am J Physiol Regul Integr Comp Physiol 2004;287:R749-58. [PubMed: 15130877]

4. Bachner D, Kreienkamp H, Weise C, Buck F, Richter D. Identification of melanin concentrating hormone $(\mathrm{MCH})$ as the natural ligand for the orphan somatostatin-like receptor 1 (SLC-1) [In Process Citation]. FEBS Lett 1999;457:522-4. [PubMed: 10471841]

5. Bednarek MA. Peptide ligands for the melanin-concentrating hormone (MCH) receptor 1. Curr Top Med Chem 2007;7:1425-32. [PubMed: 17897029]

6. Bittencourt JC, Presse F, Arias C, Peto C, Vaughan J, Nahon JL, et al. The melanin-concentrating hormone system of the rat brain: an immuno- and hybridization histochemical characterization. J Comp Neurol 1992;319:218-45. [PubMed: 1522246]

7. Bjursell M, Gerdin AK, Ploj K, Svensson D, Svensson L, Oscarsson J, et al. Melanin-concentrating hormone receptor 1 deficiency increases insulin sensitivity in obese leptin-deficient mice without affecting body weight. Diabetes 2006;55:725-33. [PubMed: 16505236] 
8. Bockamp E, Maringer M, Spangenberg C, Fees S, Fraser S, Eshkind L, et al. Of mice and models: improved animal models for biomedical research. Physiol Genomics 2002;11:115-32. [PubMed: 12464688]

9. Borowsky B, Durkin MM, Ogozalek K, Marzabadi MR, DeLeon J, Lagu B, et al. Antidepressant, anxiolytic and anorectic effects of a melanin-concentrating hormone-1 receptor antagonist. Nat Med 2002;8:825-30. [PubMed: 12118247]

10. Brown SN, Chitravanshi VC, Kawabe K, Sapru HN. Microinjections of melanin concentrating hormone into the nucleus tractus solitarius of the rat elicit depressor and bradycardic responses. Neuroscience 2007;150:796-806. [PubMed: 17988799]

11. Chambers J, Ames RS, Bergsma D, Muir A, Fitzgerald LR, Hervieu G, et al. Melanin-concentrating hormone is the cognate ligand for the orphan G-protein-coupled receptor SLC-1. Nature 1999;400:261-5. [PubMed: 10421367]

12. Chen Y, Hu C, Hsu CK, Zhang Q, Bi C, Asnicar M, et al. Targeted disruption of the melaninconcentrating hormone receptor-1 results in hyperphagia and resistance to diet-induced obesity. Endocrinology 2002;143:2469-77. [PubMed: 12072376]

13. Clegg DJ, Air EL, Benoit SC, Sakai RS, Seeley RJ, Woods SC. Intraventricular melanin-concentrating hormone stimulates water intake independent of food intake. Am J Physiol Regul Integr Comp Physiol 2003;284:R494-9. [PubMed: 12557891]

14. Della-Zuana O, Presse F, Ortola C, Duhault J, Nahon JL, Levens N. Acute and chronic administration of melanin-concentrating hormone enhances food intake and body weight in Wistar and SpragueDawley rats. Int J Obes Relat Metab Disord 2002;26:1289-95. [PubMed: 12355323]

15. Duncan EA, Proulx K, Woods SC. Central administration of melanin-concentrating hormone increases alcohol and sucrose/quinine intake in rats. Alcohol Clin Exp Res 2005;29:958-64. [PubMed: 15976521]

16. Georgescu D, Sears RM, Hommel JD, Barrot M, Bolanos CA, Marsh DJ, et al. The hypothalamic neuropeptide melanin-concentrating hormone acts in the nucleus accumbens to modulate feeding behavior and forced-swim performance. J Neurosci 2005;25:2933-40. [PubMed: 15772353]

17. Gomori A, Ishihara A, Ito M, Mashiko S, Matsushita H, Yumoto M, et al. Chronic intracerebroventricular infusion of $\mathrm{MCH}$ causes obesity in mice. Melanin-concentrating hormone. Am J Physiol Endocrinol Metab 2003;284:E583-8. [PubMed: 12453827]

18. Guesdon B, Paradis E, Samson P, Richard D. Effects of intracerebroventricular and intra-accumbens Melanin-Concentrating Hormone agonism on food intake and energy expenditure. Am J Physiol Regul Integr Comp Physiol. 2009

19. Hervieu GJ, Cluderay JE, Harrison D, Meakin J, Maycox P, Nasir S, et al. The distribution of the mRNA and protein products of the melanin-concentrating hormone $(\mathrm{MCH})$ receptor gene, slc-1, in the central nervous system of the rat. Eur J Neurosci 2000;12:1194-216. [PubMed: 10762350]

20. Ito M, Gomori A, Ishihara A, Oda Z, Mashiko S, Matsushita H, et al. Characterization of MCHmediated obesity in mice. Am J Physiol Endocrinol Metab 2003;284:E940-5. [PubMed: 12554598]

21. Jeon JY, Bradley RL, Kokkotou EG, Marino FE, Wang X, Pissios P, et al. MCH-/- mice are resistant to aging-associated increases in body weight and insulin resistance. Diabetes 2006;55:428-34. [PubMed: 16443777]

22. Kawauchi H, Kawazoe I, Tsubokawa M, Kishida M, Baker BI. Characterization of melaninconcentrating hormone in chum salmon pituitaries. Nature 1983;305:321-3. [PubMed: 6621686]

23. Kennedy AR, Todd JF, Stanley SA, Abbott CR, Small CJ, Ghatei MA, et al. Melanin-concentrating hormone $(\mathrm{MCH})$ suppresses thyroid stimulating hormone (TSH) release, in vivo and in vitro, via the hypothalamus and the pituitary. Endocrinology 2001;142:3265-8. [PubMed: 11416052]

24. Kokkotou E, Jeon JY, Wang X, Marino FE, Carlson M, Trombly DJ, et al. Mice with MCH ablation resist diet-induced obesity through strain-specific mechanisms. Am J Physiol Regul Integr Comp Physiol 2005;289:R117-24. [PubMed: 15731402]

25. Kowalski TJ, Spar BD, Weig B, Farley C, Cook J, Ghibaudi L, et al. Effects of a selective melaninconcentrating hormone 1 receptor antagonist on food intake and energy homeostasis in diet-induced obese mice. Eur J Pharmacol 2006;535:182-91. [PubMed: 16540104] 
26. Lembo PM, Grazzini E, Cao J, Hubatsch DA, Pelletier M, Hoffert C, et al. The receptor for the orexigenic peptide melanin-concentrating hormone is a G-protein-coupled receptor. Nat Cell Biol 1999;1:267-71. [PubMed: 10559938]

27. Levine AS, Morley JE. Neuropeptide Y: a potent inducer of consummatory behavior in rats. Peptides 1984;5:1025-9. [PubMed: 6549409]

28. Ludwig DS, Tritos NA, Mastaitis JW, Kulkarni R, Kokkotou E, Elmquist J, et al. Melaninconcentrating hormone overexpression in transgenic mice leads to obesity and insulin resistance. J Clin Invest 2001;107:379-86. [PubMed: 11160162]

29. Luquet S, Perez FA, Hnasko TS, Palmiter RD. NPY/AgRP neurons are essential for feeding in adult mice but can be ablated in neonates. Science 2005;310:683-5. [PubMed: 16254186]

30. Luthin DR. Anti-obesity effects of small molecule melanin-concentrating hormone receptor 1 (MCHR1) antagonists. Life sciences 2007;81:423-40. [PubMed: 17655875]

31. Lynch JK, Freeman JC, Judd AS, Iyengar R, Mulhern M, Zhao G, et al. Optimization of chromone-2carboxamide melanin concentrating hormone receptor 1 antagonists: assessment of potency, efficacy, and cardiovascular safety. J Med Chem 2006;49:6569-84. [PubMed: 17064075]

32. Marsh DJ, Weingarth DT, Novi DE, Chen HY, Trumbauer ME, Chen AS, et al. Melanin-concentrating hormone 1 receptor-deficient mice are lean, hyperactive, and hyperphagic and have altered metabolism. Proc Natl Acad Sci U S A 2002;99:3240-5. [PubMed: 11867747]

33. Mashiko S, Ishihara A, Gomori A, Moriya R, Ito M, Iwaasa H, et al. Antiobesity effect of a melaninconcentrating hormone 1 receptor antagonist in diet-induced obese mice. Endocrinology 2005;146:3080-6. [PubMed: 15817671]

34. McBriar MD. Recent advances in the discovery of melanin-concentrating hormone receptor antagonists. Curr Opin Drug Discov Devel 2006;9:496-508.

35. Messina MM, Overton JM. Cardiovascular effects of melanin-concentrating hormone. Regul Pept 2007;139:23-30. [PubMed: 17045349]

36. Morens C, Norregaard P, Receveur JM, van Dijk G, Scheurink AJ. Effects of MCH and a MCH1receptor antagonist on (palatable) food and water intake. Brain Res 2005;1062:32-8. [PubMed: 16257393]

37. Nahon JL. The melanin-concentrating hormone: from the peptide to the gene. Crit Rev Neurobiol 1994;8:221-62. [PubMed: 7850873]

38. Nahon JL. The melanocortins and melanin-concentrating hormone in the central regulation of feeding behavior and energy homeostasis. C R Biol 2006;329:623-38. discussion 53-5. [PubMed: 16860280]

39. Pereira-da-Silva M, Torsoni MA, Nourani HV, Augusto VD, Souza CT, Gasparetti AL, et al. Hypothalamic melanin-concentrating hormone is induced by cold exposure and participates in the control of energy expenditure in rats. Endocrinology 2003;144:4831-40. [PubMed: 12960043]

40. Pissios P, Bradley RL, Maratos-Flier E. Expanding the scales: The multiple roles of MCH in regulating energy balance and other biological functions. Endocr Rev 2006;27:606-20. [PubMed: 16788162]

41. Pissios P, Frank L, Kennedy AR, Porter DR, Marino FE, Liu FF, et al. Dysregulation of the mesolimbic dopamine system and reward in MCH-/- mice. Biol Psychiatry 2008;64:184-91. [PubMed: 18281019]

42. Pissios P, Ozcan U, Kokkotou E, Okada T, Liew CW, Liu S, et al. Melanin concentrating hormone is a novel regulator of islet function and growth. Diabetes 2007;56:311-9. [PubMed: 17259374]

43. Qu D, Ludwig DS, Gammeltoft S, Piper M, Pelleymounter MA, Cullen MJ, et al. A role for melaninconcentrating hormone in the central regulation of feeding behaviour. Nature 1996;380:243-7. [PubMed: 8637571]

44. Rossi M, Choi SJ, DOS, Miyoshi T, Ghatei MA, Bloom SR. Melanin-concentrating hormone acutely stimulates feeding, but chronic administration has no effect on body weight. Endocrinology 1997;138:351-5. [PubMed: 8977423]

45. Saito Y, Nagasaki H. The melanin-concentrating hormone system and its physiological functions. Results Probl Cell Differ 2008;46:159-79. [PubMed: 18227983]

46. Saito Y, Nothacker H-P, Wang Z, Lin SHS, Leslie F, Civelli O. Molecular characterization of the melanin-concentrating hormone receptor. Nature 1999;400:265-9. [PubMed: 10421368]

47. Sakamaki R, Uemoto M, Inui A, Asakawa A, Ueno N, Ishibashi C, et al. Melanin-concentrating hormone enhances sucrose intake. Int J Mol Med 2005;15:1033-9. [PubMed: 15870910] 
48. Sanchez M, Baker BI, Celis M. Melanin-concentrating hormone (MCH) antagonizes the effects of alpha- MSH and neuropeptide E-I on grooming and locomotor activities in the rat. Peptides 1997;18:393-6. [PubMed: 9145426]

49. Segal-Lieberman G, Bradley RL, Kokkotou E, Carlson M, Trombly DJ, Wang X, et al. Melaninconcentrating hormone is a critical mediator of the leptin-deficient phenotype. Proc Natl Acad Sci U S A 2003;100:10085-90. [PubMed: 12897241]

50. Shearman LP, Camacho RE, Sloan Stribling D, Zhou D, Bednarek MA, Hreniuk DL, et al. Chronic $\mathrm{MCH}-1$ receptor modulation alters appetite, body weight and adiposity in rats. Eur J Pharmacol 2003;475:37-47. [PubMed: 12954357]

51. Shimada M, Tritos NA, Lowell BB, Flier JS, Maratos-Flier E. Mice lacking melanin-concentrating hormone are hypophagic and lean. Nature 1998;396:670-4. [PubMed: 9872314]

52. Shimomura Y, Mori M, Sugo T, Ishibashi Y, Abe M, Kurokawa T, et al. Isolation and identification of melanin-concentrating hormone as the endogenous ligand of the SLC-1 receptor. Biochemical and biophysical research communications 1999;261:622-6. [PubMed: 10441476]

53. Smith DG, Qi H, Svenningsson P, Wade M, Davis RJ, Gehlert DR, et al. Behavioral and biochemical responses to d-amphetamine in MCH1 receptor knockout mice. Synapse 2008;62:128-36. [PubMed: 18000809]

54. Smith DG, Tzavara ET, Shaw J, Luecke S, Wade M, Davis R, et al. Mesolimbic dopamine supersensitivity in melanin-concentrating hormone-1 receptor-deficient mice. J Neurosci 2005;25:91422. [PubMed: 15673672]

55. Stanley BG, Leibowitz SF. Neuropeptide Y: stimulation of feeding and drinking by injection into the paraventricular nucleus. Life sciences 1984;35:2635-42. [PubMed: 6549039]

56. Tadayyon M, Welters HJ, Haynes AC, Cluderay JE, Hervieu G. Expression of melanin-concentrating hormone receptors in insulin-producing cells: $\mathrm{MCH}$ stimulates insulin release in RINm5F and CRIG1 cell-lines. Biochemical and biophysical research communications 2000;275:709-12. [PubMed: 10964727]

57. Takekawa S, Asami A, Ishihara Y, Terauchi J, Kato K, Shimomura Y, et al. T-226296: a novel, orally active and selective melanin-concentrating hormone receptor antagonist. Eur J Pharmacol 2002;438:129-35. [PubMed: 11909603]

58. Tan CP, Sano H, Iwaasa H, Pan J, Sailer AW, Hreniuk DL, et al. Melanin-concentrating hormone receptor subtypes 1 and 2: species-specific gene expression. Genomics 2002;79:785-92. [PubMed: 12036292]

59. Tavares FX, Al-Barazanji KA, Bigham EC, Bishop MJ, Britt CS, Carlton DL, et al. Potent, selective, and orally efficacious antagonists of melanin-concentrating hormone receptor 1. J Med Chem 2006;49:7095-107. [PubMed: 17125262]

60. Tyhon A, Adamantidis A, Foidart A, Grisar T, Lakaye B, Tirelli E. Mice lacking the melaninconcentrating hormone receptor-1 exhibit an atypical psychomotor susceptibility to cocaine and no conditioned cocaine response. Behav Brain Res 2006;173:94-103. [PubMed: 16839618]

61. Zheng H, Patterson LM, Morrison C, Banfield BW, Randall JA, Browning KN, et al. Melanin concentrating hormone innervation of caudal brainstem areas involved in gastrointestinal functions and energy balance. Neuroscience 2005;135:611-25. [PubMed: 16111819]

62. Zhou D, Shen Z, Strack AM, Marsh DJ, Shearman LP. Enhanced running wheel activity of both Mch1r- and Pmch-deficient mice. Regul Pept 2005;124:53-63. [PubMed: 15544841] 


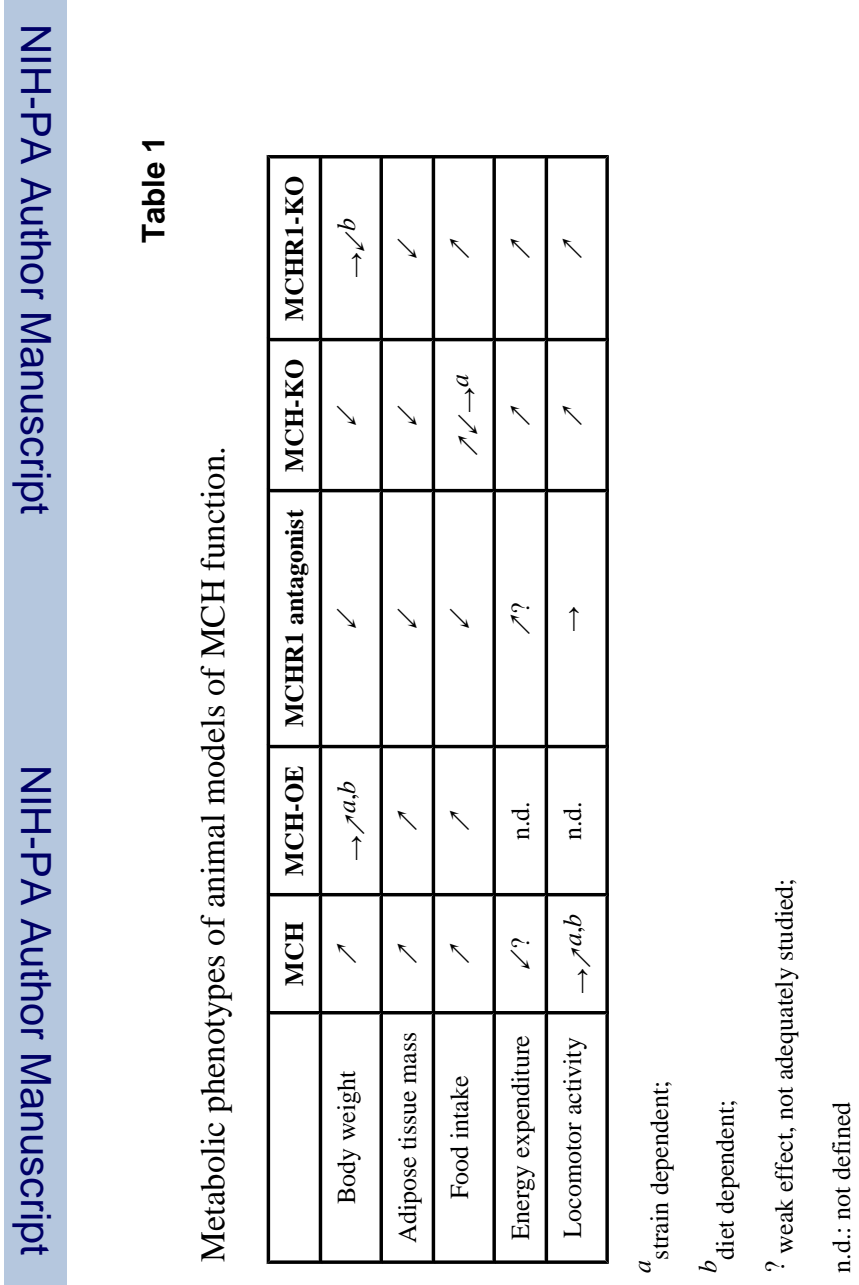

Peptides. Author manuscript; available in PMC 2010 November 10. 